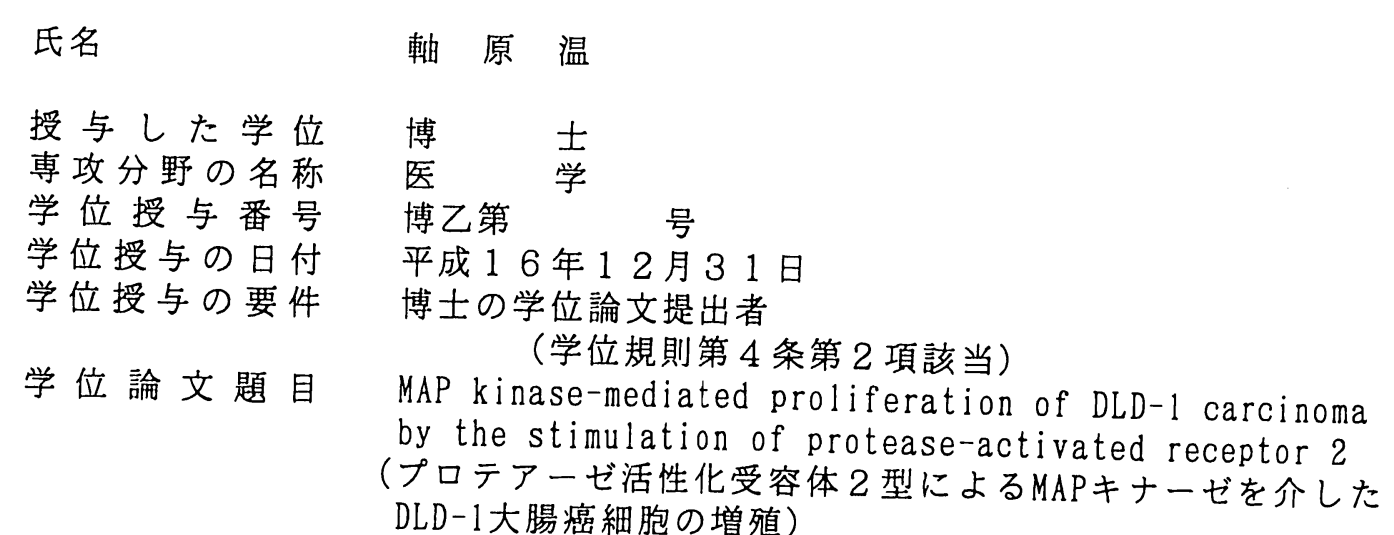

論文審査委員教授白鳥康史 教授 許 南浩 助教授 富澤一仁

学位論文内容の要旨

ヒト大腸癌細胞株 DLD-1 細胞におけるプロテアーゼ活性化受容体 (ProteaseActivated Receptor : PAR-1/PAR-2) の発現と機能について検討した。RT-PCR 法 にて、PAR-1/PAR-2 mRNA の発現が認められた。PAR-1/PAR-2 アゴニストペプチ ド添加にて、カルシウムシグナルが観察された。PAR-2 アゴニストペプチド添加に て、用量依存性、刺激時間依存性に DLD-1 細胞の増殖の有意の増加が認められたが、 この増殖六進効果は、PAR-1 アゴニストペプチドには認められなかった。Westernblotting による増殖シグナルの解析では、PAR-2 アゴニストペプチドの添加にて、 MEK1/2、p44/42 MAP kinase のリン酸化が認められたが、PAR-1 アゴニストペプ チドにおいては認められなかった。MEK Inhibitor：PD98059 添加にて、細胞増殖 の抑制が認められるとともに、p44/42 MAP kinase のリン酸化の抑制も認められた。 以上のことから、PAR-2 の活性化は MEK-MAP kinase カスケードの活性化を介し、 細胞増殖に寄与することが示唆された。

\title{
論文審査結果 の要旨
}

ヒト大腸癌細胞株DLD-1細胞におけるプロテアーゼ活性化受容体 (ProteaseActivated Receptor:PAR-1/PAR-2) について検討し、RT-PCR法にて、

PAR-1/PAR-2 mRNAの発現が認められた。PAR-2 アゴニストペプチド添加に

て、用量依存性、刺激時間依存性にDLD-1細胞の増殖に有意な増加が認めら れたが、PARー1、アゴニスト゚プチドでは、認められなかつた。Westernblottingによる增殖シグナルの解析では、PAR-2 アゴニスト゚ペプチドの添 加にて、MEK1/2,p44/42 MAP kinaseのリン酸化が認められたが、PAR-1ア当 三ストペプチドにおいては認められなかった。MEK Inhibitor:PD98059添 加に て、細胞增殖の抑制が認められるとともに, p44/42 MAP kinaseのリン 酸华の 抑制も認められた。これよりPAR-2の活性化はMEK-MAP kinaseカス ケードの 活性化を介し、細胞增殖に奇与することが示された。

よって、本研究者は博士（医学）の学位を得る資格があると認める。 